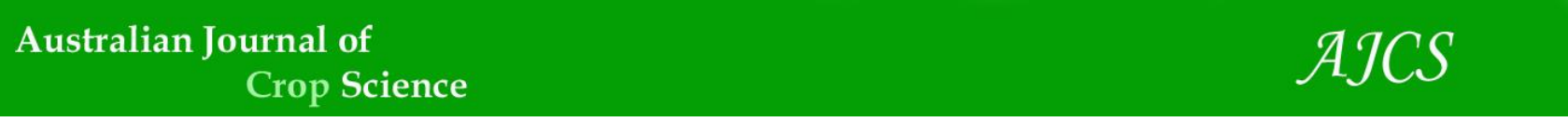

AJCS 10(7):949-955 (2016)

ISSN:1835-2707

DOI: 10.21475/ajcs.2016.10.07.p7442

\title{
Application of digital images for nitrogen status diagnosis in three Vigna unguiculata cultivars
}

\author{
Márcia Masson Mendes dos Santos ${ }^{1}$, Ester de Paiva Alves ${ }^{1}$, Benjamim Valentim da Silva ${ }^{1}$, Fabrício de \\ Oliveira Reis ${ }^{1}$, Fábio Luiz Partelli ${ }^{2}$, Paulo Roberto Cecon ${ }^{3}$, Heder Braun ${ }^{1 *}$
}

\author{
${ }^{1}$ Maranhão State University, Agroecology Graduate Program, São Luís, Maranhão State, Brazil \\ ${ }^{2}$ Federal University of Espírito Santo, University Center of North Espírito Santo, Department Plant and Biology \\ Science, São Mateus, Espírito Santo State, Brazil \\ ${ }^{3}$ Federal University of Viçosa, Departament of Estatistics, Campus Viçosa, Viçosa, Minas Gerais State, Brazil
}

\section{*Corresponding author: hederbraun@gmail.com}

\begin{abstract}
The SPAD chlorophyll meter is widely used to indirectly monitor the nitrogen $(\mathrm{N})$ status of various crops, which is important to ensure proper management of $\mathrm{N}$ fertilizers. Here, we propose that the freely available digital foliar analysis software AFSoft may be used to monitor $\mathrm{N}$ status with the same effectiveness as the SPAD meter. To verify the usefulness of AFSoft, we employed both SPAD meter readings and AFSoft note to estimate relative chlorophyll content in cowpea beans exposed to different $\mathrm{N}$ fertilization rates. The experiment followed a completely randomized design comprised of four replicates carried out in a factorial scheme, with five $\mathrm{N}$ fertilization rates $\left(0,50,100,200\right.$ and $\left.300 \mathrm{mg} \mathrm{pot}^{-1}\right)$ applied to three cowpea bean cultivars (BRS Itaim, BRS Guariba and BRS Novaera). At 45 days after emergence (DAE) of the plants, SPAD readings were obtained on the second trifoliate leaf. The whole leaf was subsequently digitally photographed and dried for the determination of total $\mathrm{N}$ concentration by applying acolour scale using $\mathrm{AFSoft}^{\circledR}$ software. There was no significant interaction observed between $\mathrm{N}$ fertilization rate and cultivar for the evaluated variables. For all cultivars, increasing the rate of $\mathrm{N}$ fertilization increased the total observed $\mathrm{N}$ concentration as determined by both SPAD index and AFSoft note. The AFSoft note value was positively correlated with the total $\mathrm{N}$ concentration ( $\mathrm{r}=0.95$, $\mathrm{P} \leq 0.05 ; \mathrm{r}=0.80, \mathrm{P} \leq 0.01 ; \mathrm{r}=0.86, \mathrm{P} \leq 0.01)$ and the SPAD readings $(\mathrm{r}=0.99, \mathrm{P} \leq 0.01 ; \mathrm{r}=0.97, \mathrm{P} \leq 0.05 ; \mathrm{r}=0.97, \mathrm{P} \leq 0.05)$ for the Itaim, Guariba and Novaera cultivars. These results suggest that $\mathrm{N}$ concentration in the leaves of cowpea bean cultivars can be estimated using AFSoft, which may serve as an alternative to SPAD meter readings.
\end{abstract}

Keywords:Vigna unguiculata, Nitrogen fertilization rates, leaf diagnostics, AFSoft software.

Abbreviations: N_nitrogen, DAE_days after emergence, SPAD_chlorophyll meter, ANOVA_analysis of variance.

\section{Introduction}

Nitrogen $(\mathrm{N})$ is responsible for the growth and development of plants. It is present in chlorophyll molecules and proteins, and is directly associated with photosynthetic activity and the translocation rates of photoassimilates (Cruz et al., 2003; Boussadia et al., 2011). Inadequate $\mathrm{N}$ supply will lead to smaller leaves, lower chlorophyll content and less biomass production, which results in reduced yield in crops (Adhikari et al., 1999; Prasertsak and Fukai, 1997). On the other hand, excess $\mathrm{N}$ leads to environmental damage by causing water and atmospheric pollution (Kaushal et al., 2011). Therefore, management strategies to increase $\mathrm{N}$ use efficiency by plants and reduce pollution are necessary.

One of the alternatives to evaluating the availability of $\mathrm{N}$ in the soil directly is measuring $\mathrm{N}$ in the leaves of the plant. As plants may show no outward effects while experiencing mild $\mathrm{N}$ deficiency, the visible effects of $\mathrm{N}$ depletion in plants may only be detected once the plant's production is significantly impaired (Fontes, 2001).Therefore, quick and practical methodologies are essential for the early diagnosis of $\mathrm{N}$ deficiency in plants. Foliar readings obtained using the SPAD-502 (Soil Plant Analysis Development) chlorophyll meter (Busato et al., 2010; Coelho et al., 2010; Pôrto et al., 2014; Costa et al., 2015; Pocojeski et al., 2015) are known to be correlated with $\mathrm{N}$ concentration in leaves (Coelho et al.,
2010), and therefore facilitate measurement of $\mathrm{N}$ status in crops (Pôrto et al., 2014; Costa et al., 2015; Pocojeski et al., 2015). Alternative methods for estimating foliar $\mathrm{N}$ concentration include Dualex ${ }^{\circledR}$ (Coelho et al., 2012), the leaf color chart (Yang et al., 2003) and recently, digital camera techniques (Li et al., 2010; Wang et al., 2014) combined with digital imaging software (Haim et al., 2012).

The SPAD chlorophyll meter is currently widely used in precision agriculture for growth monitoring, $\mathrm{N}$ diagnosis and site-specific crop management (Blackmer and Schepers, 1995; Coelho et al., 2012; Busato et al., 2010). The use of this instrument is advantageous as it is both rapid and nondestructive, whereas laboratory-based methods are more time-consuming and generally require the destruction of the plant specimen. Another advantage is that SPAD readings do not reflect excessive consumption of $\mathrm{N}$ that does not correspond to an increase in the intensity of green leaf color (Blackmer and Schepers, 1995), as the increased availability and consumption of the nutrients in question do not cause the plant to produce more chlorophyll than it needs. A disadvantage of using the SPAD-502 meter for assessing crop $\mathrm{N}$ status is its small sampling area $\left(6 \mathrm{~mm}^{2}\right)$ (Wang et al., 2014), which necessitates a large number of repeat measurements in order to obtain reliable results (Blackmer 
and Schepers, 1995). Digital leaf image processing has been proposed as an alternative to the SPAD meter, and it has the capacity to acquire sufficient data to inform decisions regarding the appropriate amount of $\mathrm{N}$ to be applied (Wang et al., 2014). Processed digital leaf images have previously been used to obtain an index which expresses the green color in leaves (Karcher and Richardson, 2003; Haim et al., 2012). AFSoft is a digital leaf image analysis program which uses supervised neural networks to classify the patterns found in leaves (Jorge and Silva, 2009). AFSoft ${ }^{\circledR}$ software is freely available, and has been utilized by Empresa Brasileira de Pesquisa Agropecuária (EMBRAPA) (Jorge and Silva, 2009); however its utility in diagnosing $\mathrm{N}$ status in crops has not yet been reported.

Cowpea beans (Vigna unguiculata) are a widely cultivated crop species, and an important food source. There is currently a lack of published data informing the quantity of $\mathrm{N}$ fertilizer that must be applied to cowpea bean crops to obtain satisfactory yields. In order to reduce the environmental contamination created by $\mathrm{N}-\mathrm{NO}_{3}$ leaching, it is important to determine the correct $\mathrm{N}$ fertilization rates for $\mathrm{N}$ application. This information is currently particularly insufficient for cowpea beans grown in humid tropical regions. In this study, experiments with varying $\mathrm{N}$ fertilization rates were carried out in a greenhouse with three cowpea bean cultivars in order to (i) analyze the relationship between AFSoft note, total N concentration and SPAD chlorophyll meter readings, (ii) establish a model for $\mathrm{N}$ status diagnosis using digital leaf images analyzed using both AFSoft software and SPAD chlorophyll meter readings, and (iii) verify the utility of these tools for $\mathrm{N}$ status diagnosis.

\section{Results}

\section{Effect of $N$ fertilization rates on evaluated variables}

Following statistical analysis, there was no detected statistically significant interaction between $\mathrm{N}$ fertilization rates and cowpea bean cultivar for all the evaluated variables. There was, however, a statistically significant effect of $\mathrm{N}$ fertilization rates regardless of cultivar for all evaluated variables (Table 2). The variation of experimental data was expressed by the coefficient of variation (CV), which is of great importance in evaluating the precision of the outcome of any study. In field conditions, a $\mathrm{CV} \leq 10 \%$ is usually considered low, $10<\mathrm{CV} \leq 20 \%$ are moderate, $20<$ $\mathrm{CV} \leq 30 \%$ are high, and $\mathrm{CV}>30 \%$ are very high (Pimentel Gomes, 1985). This general classification, however, does not consider agronomic aspects, traits under investigation, weather conditions or growing cycles (Scapim et al., 1995).

\section{Regression and correlation between total $N$ concentration, SPAD index and AFSoft note.}

Increasing $\mathrm{N}$ fertilization rates were accompanied by a significant increase in AFSoft note according to a linear model for BRS Itaim (Fig 1A), and a quadratic model for BRS Guariba and BRS Novaera cultivars (Fig 1B and C). For BRS Itaim, increasing the $\mathrm{N}$ fertilization rate by one unit corresponded to an increase of 0.55 units in AFSoft note. The application of $188 \mathrm{mg}^{-1}$ pot $^{-1}$ and $166 \mathrm{mg}^{-1}$ of $\mathrm{N}$ fertilizer led to the maximum measured AFSoft note of 4.05 and 3.82 for BRS Guariba and BRS Novaera, respectively. For BRS Itaim cultivar, $\mathrm{N}$ fertilization rates affected the total $\mathrm{N}$ concentration and SPAD index significantly with a positive linear response (Table 3). For this cultivar, increasing $\mathrm{N}$ fertilization rate by one unit increased the inferred total $\mathrm{N}$ concentration and SPAD index by 2.05 and 2.32 units, respectively. The $\mathrm{N}$ fertilization rates also significantly affected the total $\mathrm{N}$ concentration and SPAD index for BRS Guariba and BRS Novaera cultivars, both with a quadratic model response (Table 3 ). The optimum $\mathrm{N}$ fertilization rates of $275 \mathrm{mg} \mathrm{pot}^{-1}$ and $198 \mathrm{mgpot}^{-1}$ for BRS Guariba and $203 \mathrm{mg}$ pot $^{-1}$ and $173 \mathrm{mg}$ pot $^{-1}$ for and BRS Novaera led to the maximum estimated total $\mathrm{N}$ concentration and SPAD index of $44.95 \mathrm{gkg}^{-1}$ and $40.29 \mathrm{~g} \mathrm{~kg}^{-1}$; and 41.26 SPAD units and 45.17 SPAD units, respectively.

Analysis of all evaluated variables for the three cowpea bean cultivars revealed that the total $\mathrm{N}$ concentration was not dependent on cultivar. The SPAD index and AFSoft note were significantly different between the cultivars only when $\mathrm{N}$ was supplied at a rate of $100 \mathrm{mg} \mathrm{pot}^{-1}$ and $300 \mathrm{mg} \mathrm{pot}^{-1}$ (Table 4). When $\mathrm{N}$ was supplied at a rate of $100 \mathrm{mg} \mathrm{pot}^{-1}$, the SPAD index of BRS Guariba cultivar was lower than BRS Novaera. However, when $\mathrm{N}$ was supplied at $300 \mathrm{mg} \mathrm{pot}^{-1}$, the AFSoft note of BRS Guariba and BRS Novaera were lower than that of the BRS Itaim cultivar.

There was a significant positive linear relationship between the total $\mathrm{N}$ concentration and the SPAD index, which was similarly observed using AFSoft note. There were also significant positive linear relationships observed between the SPAD index and AFSoft note for all the measured cowpea bean cultivars (Table 5). The determination coefficient $\left(r^{2}\right)$ in different cultivars varied from 0.64 to 0.99 . There were positive and significant correlations between all the evaluated variables (Table 5). The AFSoft note was significantly positively correlated to the total $\mathrm{N}$ concentration and SPAD index. For all three cultivars, the AFSoft note had a smaller correlation coefficient with the total $\mathrm{N}$ concentration $\left(\mathrm{r}=0.80^{*}\right)$ for BRS Guariba cultivar, and showed the high coefficient of correlation $\left(\mathrm{r}=0.99^{*}\right)$ with the SPAD index for BRS Itaim (Table 5).

\section{Discussion}

Increased $\mathrm{N}$ fertilization rates resulted in a significant increase in total $\mathrm{N}$ concentration, SPAD index and AFSoft note for all cultivars (Fig 1 and Table 3). These results are in agreement with the results obtained for Phaseolus vulgaris culture (Sant'ana et al., 2010), Oryza sativa (Pocojeski et al., 2015), Cucurbita pepo and Cucumis sativus (Pôrto et al., 2011; 2014), and with Solanum tuberosum (Coelho et al., 2010), who similarly measured the effect of $\mathrm{N}$ fertilization rates on total $\mathrm{N}$ concentration in leaves by SPAD index. Furthermore, these results corroborate the results observed by other authors for Cucurbita moschata (Swiader and Moore, 2002), Gossypium hirsutum (Neves et al., 2005), Solanum tuberosum (Gil et al., 2002; Coelho et al., 2010), Phaseolus vulgaris (Silveira et al., 2003), Lycopersicon esculentum (Ferreira et al., 2006) and Cucurbita pepo (Pôrto et al., 2011), in which an increase in chlorophyll levels and/or SPAD index values in leaves was detected with increasing $\mathrm{N}$ fertilization rates. The increase in SPAD index with increasing $\mathrm{N}$ fertilization rates occurs because $\mathrm{N}$ is essential for the synthesis and structure of chlorophyll molecules. Therefore, an increase in $\mathrm{N}$ supplied to plants will, to a limited extent, lead to an increase in chlorophyll content and increase the intensity of green color detected in the leaves (Fontes and Araújo, 2007). Our results, however, do not corroborate the results observed by Silva et al. (2012), who surmised that $\mathrm{N}$ topdressing in crambe leaves had no significant effect, according to SPAD chlorophyll meter readings and $\mathrm{N}$ concentration calculations. The lack of influence of $\mathrm{N}$ topdressing may, in this case, be due to the soil dynamics and lack of rain for the duration of their study. 
Table 1. Dosage of nitrogen $(\mathrm{N})$ fertilizer applied.

\begin{tabular}{lccccc}
\hline \multirow{2}{*}{ NFraction } & \multicolumn{5}{c}{${\mathrm{N} \text { fertilization rates }\left(\mathrm{mg} \mathrm{pot}^{-1}\right)}$} \\
\cline { 2 - 6 } & 0.0 & 0.5 & 1.0 & 2.0 & 3.0 \\
\hline Planting & $100 \%$ & $50 \%$ & $50 \%$ & $33.3 \%$ \\
$10 \mathrm{DAE}^{1}$ & & $50 \%$ & $50 \%$ & $33.3 \%$ \\
$17 \mathrm{DAE}^{1}$ & & & & $33.3 \%$ \\
\hline
\end{tabular}

${ }^{1}$ Days after emergence. The plastic pot had $6 \mathrm{dm}^{3}$ capacity and five $\mathrm{kg}$ the soil.
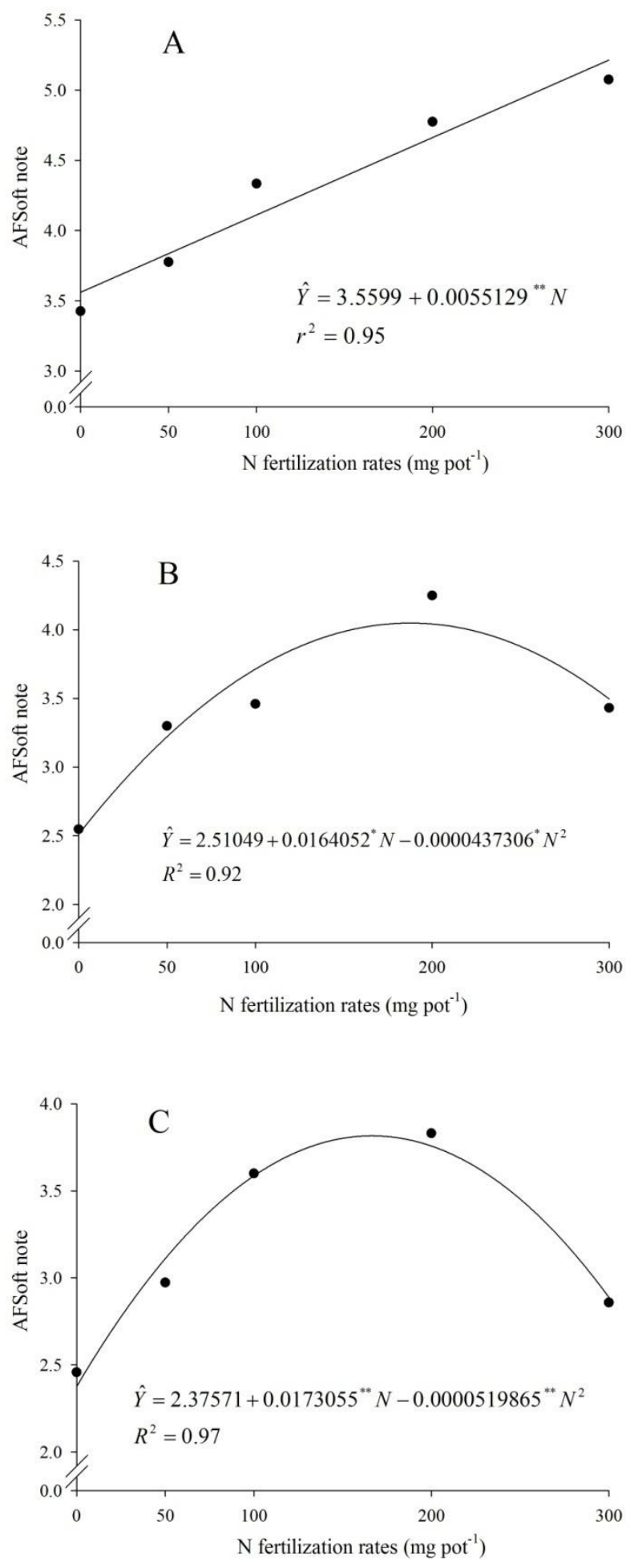

Fig 1. AFSoft note of BRS Itaim (A), BRS Guariba (B) and BRS Novaera (C) cultivars as function of nitrogen fertilization rates.** and $*$ : significant at $1 \%$ and $5 \%$ of probability by the $t$ test, respectively. 
Table 2. Analysis of variance of SPAD index, total N concentration and AFSoft index affected by N fertilization rates and cowpea cultivars.

\begin{tabular}{lccc}
\hline Source of variation & SPAD index & Total N concentration $\left(\mathrm{g} \mathrm{kg}^{-1}\right)$ & AFSoft index \\
\hline Cultivars $(\mathrm{C})$ & $\mathrm{P} \leq 0.01$ & $\mathrm{P} \leq 0.001$ & $\mathrm{P} \leq 0.0001$ \\
N fertilization rates(N) & $\mathrm{P} \leq 0.0001$ & $\mathrm{P} \leq 0.05$ & $\mathrm{P} \leq 0.0001$ \\
C x N & $\mathrm{P}>0.99$ & $\mathrm{P}>0.99$ & $\mathrm{P}=32.64$ \\
\hline CV\% & 7.85 & 11.24 & 16.27 \\
\hline
\end{tabular}

Table 3. Total nitrogen concentration and SPAD index of BRS Itaim, BRS Guariba and BRS Novaera cultivars as function of nitrogen fertilization rates.

\begin{tabular}{llll}
\hline Cultivars & Evaluated variables & Adjusted equation & $\mathrm{r}^{2} / \mathrm{R}^{2}$ \\
\hline \multirow{2}{*}{ BRS Itaim } & N concentration $\left(\mathrm{g} \mathrm{kg}^{-1}\right)$ & $\hat{\mathrm{Y}}=34.5625+0.0205889^{* * \mathrm{~N}}$ & 0.96 \\
& SPAD index & $\hat{\mathrm{Y}}=38.6875+0.0232177 * * \mathrm{~N}$ & 0.91 \\
\hline \multirow{2}{*}{ BRS Guariba } & N concentration $\left(\mathrm{g} \mathrm{kg}^{-1}\right)$ & $\hat{\mathrm{Y}}=39.2961+0.0410656^{*} \mathrm{~N}-0.000074564^{\circ} \mathrm{N}^{2}$ & 0.95 \\
& SPAD index & $\hat{\mathrm{Y}}=34.9641+0.0620669^{\circ} \mathrm{N}-0.000152905^{\circ} \mathrm{N}^{2}$ & 0.82 \\
\hline \multirow{2}{*}{ BRSNovaera } & N concentration $\left(\mathrm{g} \mathrm{kg}^{-1}\right)$ & $\hat{\mathrm{Y}}=33.1689+0.0720924 * * \mathrm{~N}-0.000182369^{* *} \mathrm{~N}^{2}$ & 0.98 \\
& SPAD index & $\hat{\mathrm{Y}}=37.5327+0.0880103 * \mathrm{~N}-0.000253651^{*} \mathrm{~N}^{2}$ & 0.90 \\
\hline \multirow{2}{*}{$* *$ and $^{\circ}:$ significant at $1 \%, 5 \%$ and $10 \%$ of probability by the $t$ test, respectively. } &
\end{tabular}

Table 4. SPAD index, total N concentration and AFSoft index of BRS Itaim, BRS Guariba and BRS Novaera cultivars as function of nitrogen fertilization rates.

\begin{tabular}{|c|c|c|c|c|c|}
\hline \multirow{3}{*}{ Cultivars } & \multicolumn{5}{|c|}{$\mathrm{N}$ fertilization rates $\left(\mathrm{mg} \mathrm{pot}^{-1}\right)$} \\
\hline & 0.0 & 0.5 & 1.0 & 2.0 & 3.0 \\
\hline & \multicolumn{5}{|c|}{ SPAD index } \\
\hline BRS Itaim & $37.8 \mathrm{~A}^{1}$ & $39.7 \mathrm{~A}$ & $42.6 \mathrm{AB}$ & $43.9 \mathrm{~A}$ & $44.8 \mathrm{~A}$ \\
\hline BRS Guariba & $35.5 \mathrm{~A}$ & $37.5 \mathrm{~A}$ & $38.1 \mathrm{~B}$ & $42.8 \mathrm{~A}$ & $39.7 \mathrm{~A}$ \\
\hline \multirow[t]{2}{*}{ BRS Novaera } & $38.3 \mathrm{~A}$ & $39.7 \mathrm{~A}$ & $44.4 \mathrm{~A}$ & $45.2 \mathrm{~A}$ & $41.1 \mathrm{~A}$ \\
\hline & \multicolumn{5}{|c|}{ Total $\mathrm{N}$ concentration $\left(\mathrm{g} \mathrm{kg}^{-1}\right)$} \\
\hline BRS Itaim & $34.9 \mathrm{~A}$ & $35.2 \mathrm{~A}$ & $37.6 \mathrm{~A}$ & $39.2 \mathrm{~A}$ & $40.5 \mathrm{~A}$ \\
\hline BRS Guariba & $39.7 \mathrm{~A}$ & $40.3 \mathrm{~A}$ & $42.9 \mathrm{~A}$ & $44.8 \mathrm{~A}$ & $42.8 \mathrm{~A}$ \\
\hline \multirow[t]{2}{*}{ BRS Novaera } & $33.2 \mathrm{~A}$ & $36.5 \mathrm{~A}$ & $38.1 \mathrm{~A}$ & $40.8 \mathrm{~A}$ & $38.7 \mathrm{~A}$ \\
\hline & \multicolumn{5}{|c|}{ AFSoft note } \\
\hline BRS Itaim & $3.42 \mathrm{~A}$ & $3.77 \mathrm{~A}$ & $4.33 \mathrm{~A}$ & $4.77 \mathrm{~A}$ & $5.07 \mathrm{~A}$ \\
\hline BRS Guariba & $2.54 \mathrm{~A}$ & $3.29 \mathrm{~A}$ & $3.45 \mathrm{~A}$ & $4.24 \mathrm{~A}$ & $3.43 \mathrm{~B}$ \\
\hline BRS Novaera & $2.45 \mathrm{~A}$ & $2.97 \mathrm{~A}$ & $3.59 \mathrm{~A}$ & $3.83 \mathrm{~A}$ & $2.85 \mathrm{~B}$ \\
\hline
\end{tabular}

Table 5. Linear regression models adjusted between dependent evaluated variables in cowpea cultivars with their determination coefficient $\left(\mathrm{r}^{2}\right)$ and of the correlation coefficient $(\mathrm{r})$.

\begin{tabular}{|c|c|c|c|c|}
\hline \multicolumn{2}{|l|}{ Variables } & \multirow[b]{2}{*}{ Adjusted equation } & \multirow{2}{*}{$r^{2}$} & \multirow[b]{2}{*}{$\mathrm{r}$} \\
\hline Dependent & Independent & & & \\
\hline \multicolumn{5}{|l|}{ BRS Itaim cultivar } \\
\hline Total $\mathrm{N}$ concentration $\left(\mathrm{g} \mathrm{kg}^{-1}\right)$ & SPAD index & $\hat{\mathrm{Y}}=3.98773+0.797282^{*}$ & 0.86 & $0.93 * *$ \\
\hline Total $\mathrm{N}$ concentration $\left(\mathrm{g} \mathrm{kg}^{-1}\right)$ & AFSoft note & $\hat{\mathrm{Y}}=22.2413+3.50689^{* *}$ & 0.90 & $0.95 * *$ \\
\hline SPAD index & AFSoft note & $\hat{\mathrm{Y}}=23.4062+4.27895 * *$ & 0.99 & $0.99 * *$ \\
\hline \multicolumn{5}{|l|}{ BRS Guariba cultivar } \\
\hline Total $\mathrm{N}$ concentration $\left(\mathrm{g} \mathrm{kg}^{-1}\right)$ & SPAD index & $\hat{\mathrm{Y}}=13.0495+0.761734 *$ & 0.73 & $0.85 *$ \\
\hline Total $\mathrm{N}$ concentration $\left(\mathrm{g} \mathrm{kg}^{-1}\right)$ & AFSoft note & $\hat{\mathrm{Y}}=31.7254+3.17478^{*}$ & 0.64 & $0.80 *$ \\
\hline SPAD index & AFSoft note & $\hat{\mathrm{Y}}=24.0609+4.30225^{* *}$ & 0.94 & $0.97 * *$ \\
\hline \multicolumn{5}{|l|}{ BRS Novaera cultivar } \\
\hline Total $\mathrm{N}$ concentration $\left(\mathrm{g} \mathrm{kg}^{-1}\right)$ & SPAD index & $\hat{\mathrm{Y}}=4.23647+0.793076^{*}$ & 0.76 & $0.87 *$ \\
\hline Total $\mathrm{N}$ concentration $\left(\mathrm{g} \mathrm{kg}^{-1}\right)$ & AFSoft note & $\hat{\mathrm{Y}}=24.0706+4.22187^{*}$ & 0.75 & $0.86^{*}$ \\
\hline SPAD index & AFSoft note & $\hat{Y}=25.2254+5.25463 * *$ & 0.95 & $0.97 *$ \\
\hline
\end{tabular}

$* *, *$ and ${ }^{\circ}$ : significant at $1 \%, 5 \%$ and $10 \%$ of probability by the $t$ test, respectively. 
Positive linear relationships were observed between all evaluated variables (Table 5). This indicates that increasing the $\mathrm{N}$ fertilization rate increases the amount of $\mathrm{N}$ in the leaves of these cowpea beans, which corresponds to a higher measured SPAD index. Teixeira Filho et al. (2010) obtained a similar result with Triticum aestivum culture, Costa et al. (2015) with Urochloa brizantha, Pocojeski et al. (2015) with Oryza sativa, Porto et al. (2014) with Cucumis sativus and Coelho et al. (2010) also found a positive and significant correlation between total $\mathrm{N}$ concentration and SPAD index in two potato cultivars (Ágata and Asterix cultivars), which further confirms the results presented here. Paradoxically, Silva et al. (2012) reported that there was no significant correlation between chlorophyll meter (SPAD index) and leaf $\mathrm{N}$ concentration in crambe crops, during full flowering.

The results presented here corroborate the results observed by Haim et al. (2012), who reported significant linear and positive correlations between $\mathrm{N}$ concentration and chlorophyll index, $\mathrm{N}$ concentration and AFSoft note, and the chlorophyll index and AFSoft note. It was observed, except the correlation between total $\mathrm{N}$ concentration and SPAD index in Carioca $\left(\mathrm{r}=0.35^{\mathrm{NS}}\right)$ and Iraí $\left(\mathrm{r}=0.15^{\mathrm{NS}}\right)$ cultivars; and the correlation between total $\mathrm{N}$ concentration and AFSoft note for Carioca cultivar $\left(\mathrm{r}=0.47^{\mathrm{NS}}\right)$. These authors conclude that due to the observed significant correlation between the concentration of $\mathrm{N}$ fertilizer applied and the measured AFSoft note, digital image analysis adequately evaluated the green status of bean leaves.

The use of SPAD chlorophyll meters to evaluate $\mathrm{N}$ status is advantageous due to the low propensity to consume excess $\mathrm{N}$ by plants (Fontes, 2001). This is driven by the form in which this nutrient is accumulated in the leaf, since excess $\mathrm{N}$ accumulates as nitrate in the vacuole (Fontes, 2001).

\section{Materials and Methods}

\section{Experimental site and soil sampling}

The experiments were conducted in a greenhouse under a natural photoperiod during the period of 2013/2014. The greenhouse is located adjacent to the Maranhão State University - UEMA, São Luís, Maranhão State, Brazil, with geographical coordinates $2^{\circ} 30^{\prime} 00^{\prime}$ ' $\mathrm{S}$ and $44^{\circ} 18^{\prime} 00^{\prime}$ ' W. The region has a hot and semi-humid equatorial climate and two well-defined seasons: a rainy season that extends from January to June and a dry season with a marked water deficit from July to December.

The soil in which the experiment was conducted is classified as Arenic Hapludult. Soil samples were taken at depths of $0-20 \mathrm{~cm}$ to quantify its chemical and physical characteristics. The soil was dried under shade, sifted and sent to the laboratory for analysis, and was found to contain 4.4 of $\mathrm{pH}$ (via $\mathrm{CaCl}_{2}$ determination); $9.0 \mathrm{mg} \mathrm{dm}^{-3}$ of $\mathrm{P} ; 36.0$ $\mathrm{mg} \mathrm{dm}{ }^{-3}$ of $\mathrm{H}^{+}+\mathrm{Al}^{3+} ; 2.1 \mathrm{mg} \mathrm{dm}^{-3}$ of $\mathrm{K}^{+} ; 7.0 \mathrm{mg} \mathrm{dm}^{-3}$ of $\mathrm{Ca}^{2+}$; $6.0 \mathrm{mg} \mathrm{dm}{ }^{-3}$ of $\mathrm{Mg}^{2+} ; 17.9$ sum of bases $\mathrm{cmol}_{\mathrm{c}} \mathrm{dm}^{-3} ; 23.5 \mathrm{~g}$ $\mathrm{dm}^{-3}$ of organic matter; $33.0 \%$ of base saturation, very sandy texture, $330 \mathrm{~g} \mathrm{~kg}^{-1}$ of coarse sand; $510 \mathrm{~g} \mathrm{~kg}^{-1}$ of fine sand; 60 $\mathrm{g} \mathrm{kg}^{-1}$ of silt and $100 \mathrm{~g} \mathrm{~kg}^{-1}$ of clay.

\section{Treatment and experimental design}

Each plastic $6 \mathrm{dm}^{3}$ pot was designated as an experimental unit. The soil was weighed immediately before it was added to the pots, so that all pots maintained the same weight $(5 \mathrm{~kg})$ before the experiment.

The experiment followed a completely randomized design, with four replicates carried out in a factorial scheme comprised of three cowpea bean cultivars (BRS Novaera, BRS Itaim and BRS Guariba) and five $\mathrm{N}$ fertilization rates $(0$, 50, 100, 200 and $300 \mathrm{mg}$ pot $^{-1}$ ) totaling 60 experimental units. $\mathrm{N}$ was supplied in the form of urea, which is comprised of $45 \% \mathrm{~N}$. Due to the potential for leaching in sandy soil, and in order to ensure that the applied $\mathrm{N}$ is better utilized by the bean plants, a percentage of the total $\mathrm{N}$ fertilizer dosage was applied at planting, 10 days after emergence (DAE) and 17 DAE for each tested fertilization rate as described in Table 1.

\section{Liming, planting and fertilizer application}

The seeds of BRS Novaera and BRS Itaim cultivars were acquired from Embrapa Meio Norte. The BRS Guariba cultivar was acquired from seeds bank at Maranhão State University. Dolomitic limestone was applied to address insufficiencies according the soil chemical analysis results. After lime application, the pots remained incubated for a period of 20 days in order to raise the base saturation to $70 \%$. Two days prior to planting the seeds, $200 \mathrm{mg} \mathrm{kg}^{-1}$ of $\mathrm{P}_{2} \mathrm{O}_{5}$ as simple superphosphate and $200 \mathrm{mg} \mathrm{kg}^{-1}$ of $\mathrm{K}_{2} \mathrm{O}$ as potassium chloride were applied to the soil. Six seeds were planted per pot on January $29^{\text {th }}, 2014$. Thinning was performed one week after emergence, leaving three cowpea bean plants per pot. Irrigation was performed according to the necessity of the soil culture.

\section{Variables analyzed}

At 45 days after emergence (DAE), readings were carried out between 09:00 and 11:00 a.m with the SPAD-502 chlorophyll meter on the second trifoliate leaf in two randomly selected plants per pot. A mean of ten readings (five readings per leaf) were obtained for each $\mathrm{N}$ fertilization rate and each replicate. The same leaves were then detached from the plants and sanitized with $1 \%$ sodium hypochlorite (v/v). Immediately after complete sanitization, the leaves were scanned to obtain digital images in .jpeg format with a resolution of 200 dpi in an HP 2050 J510 scanner. Following this, the leaves were dried by forced air circulation at $70{ }^{\circ} \mathrm{C}$ until constant mass was achieved, and subsequently ground in a Willey-type grinding mill coupled to a $1 \mathrm{~mm}$ mesh screen. Replicate leaf samples obtained in this manner for each $\mathrm{N}$ fertilization rate were subjected to $\mathrm{H}_{2} \mathrm{SO}_{4}-\mathrm{H}_{2} \mathrm{O}_{2}$ digestion in order to determine total $\mathrm{N}$ concentration by the Kjeldahl method, according to the standard method by Tedesco et al. (1995). The total $\mathrm{N}$ concentration calculated in this manner was expressed in $\mathrm{g} \mathrm{kg}^{-1}$.

Six patterns of leaf colour were identified in the digital leaf images by AFSoft ${ }^{\circledR}$ software. After the patterns were defined, the images were classified according to the proportion of area occupied by each pattern. Thereafter, the leaf images were classified according to a scale which ranged from 0 (yellow) to 5 (dark green), according to recommendations described by Haim et al. (2012). The frequency of occurrence of each pattern on each leaf was multiplied by the corresponding scale, which supplied the index of each pattern. For each plant, the AFSoft ${ }^{\circledR}$ note was calculated by the sum of the index for both measured leaves.

\section{Statistical analysis}

In a preliminary analysis, a box-plot was generated for the data. To test the assumptions of the variance analysis model, Lilliefors test was used to assess the normality of model residuals, and Barttlet and Cochran tests were then used to assess homogeneity of the variances, both at $\mathrm{P} \leq 0.05$. The 
obtained results were not transformed. Subsequently, all of the data were subjected to analysis of variance (ANOVA) and regression modelling. Significant interactions between $\mathrm{N}$ fertilization rates and cultivars for each dependent variable evaluated were identified with $\mathrm{P} \leq 0.05$. The means of qualitative factors (cultivars) were compared by Tukey's test, with a $5 \%$ probability level. The quantitative factor $(\mathrm{N}$ fertilization rates) was adjusted to a linear regression model to express the relationship between the dependent and independent variable. The regression models were chosen based on the observed response and the significance of the regression coefficients, by using a $t$-test up to $10 \%$ probability; and on the equations coefficients of determination value, which are calculated by the relationship between the square sum of regression and square sum of treatment. The data were further analyzed by simple Pearson's correlation analysis (r) in order to measure the relationship between two dependent variables, to verify the existence of a relationship between the two variables, and to determine if a change in one variable is accompanied by a change in another. After linear correlation analyses, it was possible to estimate the simple linear regression equation, $\hat{Y}=\hat{\beta}_{0}+\hat{\beta}_{1} X_{i}$, for all dependent variables. All statistical analyses were executed using SAEG (System for Statistical and Genetic Analyses- version 9.1).

\section{Conclusions}

The rate at which $\mathrm{N}$ fertilizer is supplied to the plant has a positive influence on the total $\mathrm{N}$ concentration, which can be measured in the leaves by both SPAD index and AFSoft note. For each $\mathrm{N}$ fertilization rate, $\mathrm{N}$ concentration is not influenced by the cultivar. AFSoft note and SPAD index can therefore be used to determine nitrogen status in cowpea bean plants. Further investigations are necessary to determine the utility of AFSoft software in identifying leaf patterns and their significance in ascertaining overall leaf health.

\section{Acknowledgments}

The author would like to thank CNPq, UEMA and FAPEMA for their financial support and scholarships. The corresponding author would like to thank Foundation to Research Support in the State of Maranhão (FAPEMA) for Fellow of Productivity in Research. Last Edit - English editing \& proofreading of Scientific Manuscripts is also acknowledged.

\section{References}

Adhikari C, Bronson KF, Panuallah GM, Regmi AP, Saha PK, Dobermann A, Olk DC, Hobbs PR, Pasuquin E (1999) On-farm soil $\mathrm{N}$ supply and $\mathrm{N}$ nutrition in the rice-wheat system of Nepal and Bangladesh. Field Crops Res. 64(3):273-286.

Blackmer TM, Schepers JS (1995) Use of a chlorophyll meter to monitor nitrogen status and schedule fertigation for corn. J Prod Agric. 8(1):56-60.

Boussadia O, Steppe K, Zgallai H, Ben El Hadj B, Braham M, Lemeur R, Van Labeke MC (2011) Nondestructive determination of nitrogen and chlorophyll content in olive tree leaves and the relation with photosynthesis and fluorescence parameters. Photosynthetica. 49(1):149-153.

Busato C, Fontes PCR, Braun H, Cecon PR (2010) Seasonal variation and threshold values for chlorophyll meter readings on leaves of potato cultivars. J Plant Nutr. $33: 2148-2156$.
Coelho FS, Fontes PCR, Finger FL, Cecon PR (2012) Avaliação do estado nutricional do nitrogênio em batateira por meio de polifenóis e clorofila na folha. Pesqui Agropec Bras. 47(4):584-592.

Coelho FS, Fontes PCR, Puiatti M, Neves JCL, Silva MC de $C$ (2010) Dose de nitrogênio associada à produtividade de batata e índices do estado de nitrogênio na folha. R Bras Ci Solo. 34(4):1175-1183.

Costa JPR, Caputti GP, Galzerano L, Silva WL, Ruggieri AC, Malheiros EB (2015) Relative chlorophyll contents in the evaluation of the nutritional status of nitrogen from xaraes palisade grass and determination of critical nitrogen sufficiency index. Acta Sci. 37(2):109-114.

Cruz JL, Mosquim PR, Pelacani CR, Araújo WL, DaMatta FM (2003) Carbon partitioning and assimilation as affected by nitrogen deficiency in cassava. Photosynthetica. 41(2):201-207.

Ferreira MMM, Ferreira GB, Fontes PCR, Dantas JP (2006) Índice SPAD e teor de clorofila no limbo foliar do tomateiro em função de doses de nitrogênio e da adubação orgânica, em duas épocas de cultivo. R Ceres. 53(305):8392.

Fontes PCR, Araújo C (2007) Adubação nitrogenada de hortaliças: princípios e práticas com o tomateiro. Viçosa: Universidade Federal de Viçosa, 148p.

Fontes PCR (2001) Diagnóstico do estado nutricional das plantas. Viçosa: Universidade Federal de Viçosa, 122p.

Gil PT, Fontes PCR, Cecon PR, Ferreira FA (2002) Índice SPAD para o diagnóstico do estado de nitrogênio e para o prognóstico da produtividade de batata. Hort Bras. 20(4): 611-615

Haim PG, Zoffoli BC, Zonta E, Araújo AP (2012) Diagnose nutricional de nitrogênio em folhas de feijoeiro pela análise digital de imagens. Pesqui Agropec Bras. 47(10):15461549.

Jorge LA de C, Silva DJ da CB (2009) AFSoft: manual de utilização. São Carlos: Embrapa Instrumentação Agropecuária, 20p.

Karcher DE, Richardson MD (2003) Quantifying turfgrass color using digital image analysis. Crop Sci. 43:943-951.

Kaushal SS, Groffman PM, Band LE, Elliott EM, Shields CA, Kendall C (2011) Tracking nonpoint source nitrogen pollution in human-impacted watersheds. Environ Sci Technol. 45(19): 8225-8232.

Li Y, Chen D, Walker CN, Angus JF (2010) Estimating the nitrogen status of crops using a digital camera. Field Crops Res. 118(3):221-227.

Neves OSC, Carvalho JG de, Martins FAD, Pádua TRP de, Pinho PJ de (2005) Uso do SPAD-502 na avaliação dos teores foliares de clorofila, nitrogênio, enxofre, ferro e manganês do algodoeiro herbáceo. Pesqui Agropec Bras. 40(5):517-521.

Pimentel-Gomes F (1985) Curso de estatística experimental. São Paulo: Esalq, 467 p.

Pocojeski E, Silva LS, Kaefer S, Moro VJ, Griebeler G (2015) Uso do clorofilômetro no monitoramento nutricional de arroz irrigado com vistas ao manejo da adubação nitrogenada. R Ceres. 62(3):310-318.

Pôrto MLA, Puiatti M, Fontes PCR, Cecon PR, Alves JC, Arruda JA (2011) Índice SPAD para o diagnóstico do estado de nitrogênio na cultura da abobrinha. Hort Bras. 29(3):311-315.

Pôrto MLA, Puiatti M, Fontes PCR, Cecon PR, Alves JC (2014) Índice SPAD para o diagnóstico do estado de nitrogênio na cultura do pepino japonês em ambiente protegido. Hort Bras. 32(3):292-296. 
Prasertsak A, Fukai S (1997) Nitrogen availability and water stress interaction on rice growth and yield. Field Crops Res. 52(3):249-260.

Sant'ana EVP, Santos AB, Silveira PM (2010) Adubação nitrogenada na produtividade, leitura SPAD e teor de nitrogênio em folhas de feijoeiro. Pesqui Agropec Trop. 40(4):491-496.

Silva TRB, Reis ACS, Maciel CDG (2012) Relationship between chlorophyll meter readings and total $\mathrm{N}$ in crambe leaves as affected by nitrogen topdressing. Industrial Crops Prod. 39:135-138.

Silveira PM, Braz AJBP, Didonet AD (2003) Uso do clorofilômetro como indicador da necessidade de adubação nitrogenada no feijoeiro. Pesqui Agropec Bras. 38(9):10831087.

Swiader JM, Moore A (2002) SPAD chlorophyll response to nitrogen fertilization and evaluation of nitrogen status in dryland and irrigated pumpkins. J Plant Nutr.25(5):10891100 .
Tedesco MJ, Gianello C, Bissani CA, Bohnen H, Volkweiss SJ (1995) Análise de solos, plantas eoutros materiais. Porto Alegre: UFRGS.

Teixeira Filho MCM, Buzetti S, Andreotti M, ARF O, Benett, CGS (2010) Doses, fontes e épocas de aplicação de nitrogênio em trigo irrigado em plantio direto. Pesqui Agropec Bras. 45(8):797-804.

Wang Y, Wang D, Shi P, Omasa K (2014) Estimating rice chlorophyll content and leaf nitrogen concentration with a digital still color camera under natural light. Plant Methods. 10:1-11.

Yang W-H, Peng S, HuangJ, Sanico AL, Buresh RJ, Witt C (2003) Using leaf color charts to estimate leaf nitrogen status of rice. Agron J. 95(1):212-217.

Scapim CAS, Carvalho CGP de, Cruz CD (1995) Uma proposta de classificação dos coeficientes de variação para a cultura do milho. Pesqui Agropec Bras. 30(5):683-686. 